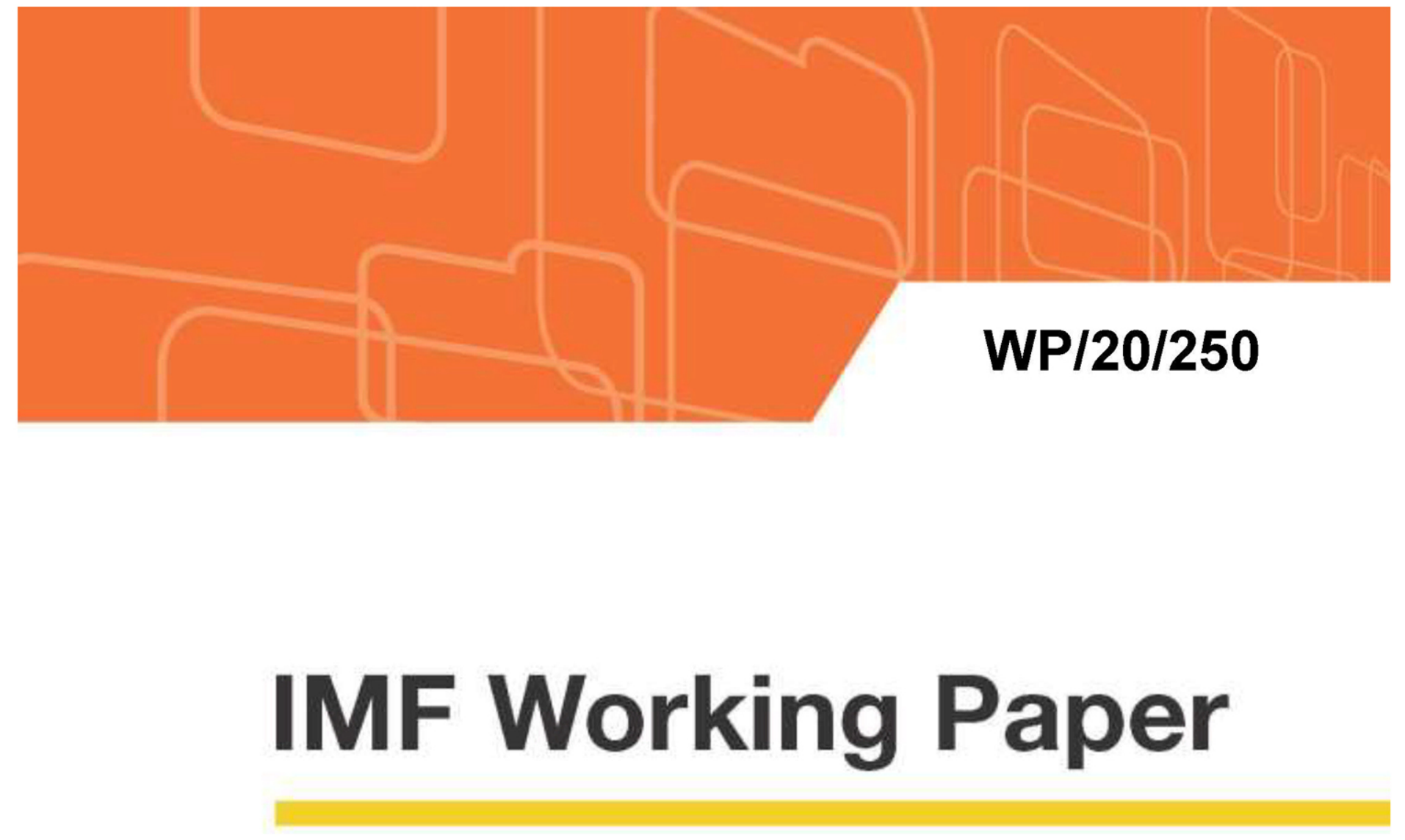

\title{
Enhancing Fiscal Transparency and Reporting in India
}

by Patrick Blagrave and Fabien Gonguet

IMF Working Papers describe research in progress by the author(s) and are published to elicit comments and to encourage debate. The views expressed in IMF Working Papers are those of the author(s) and do not necessarily represent the views of the IMF, its Executive Board, or IMF management. 


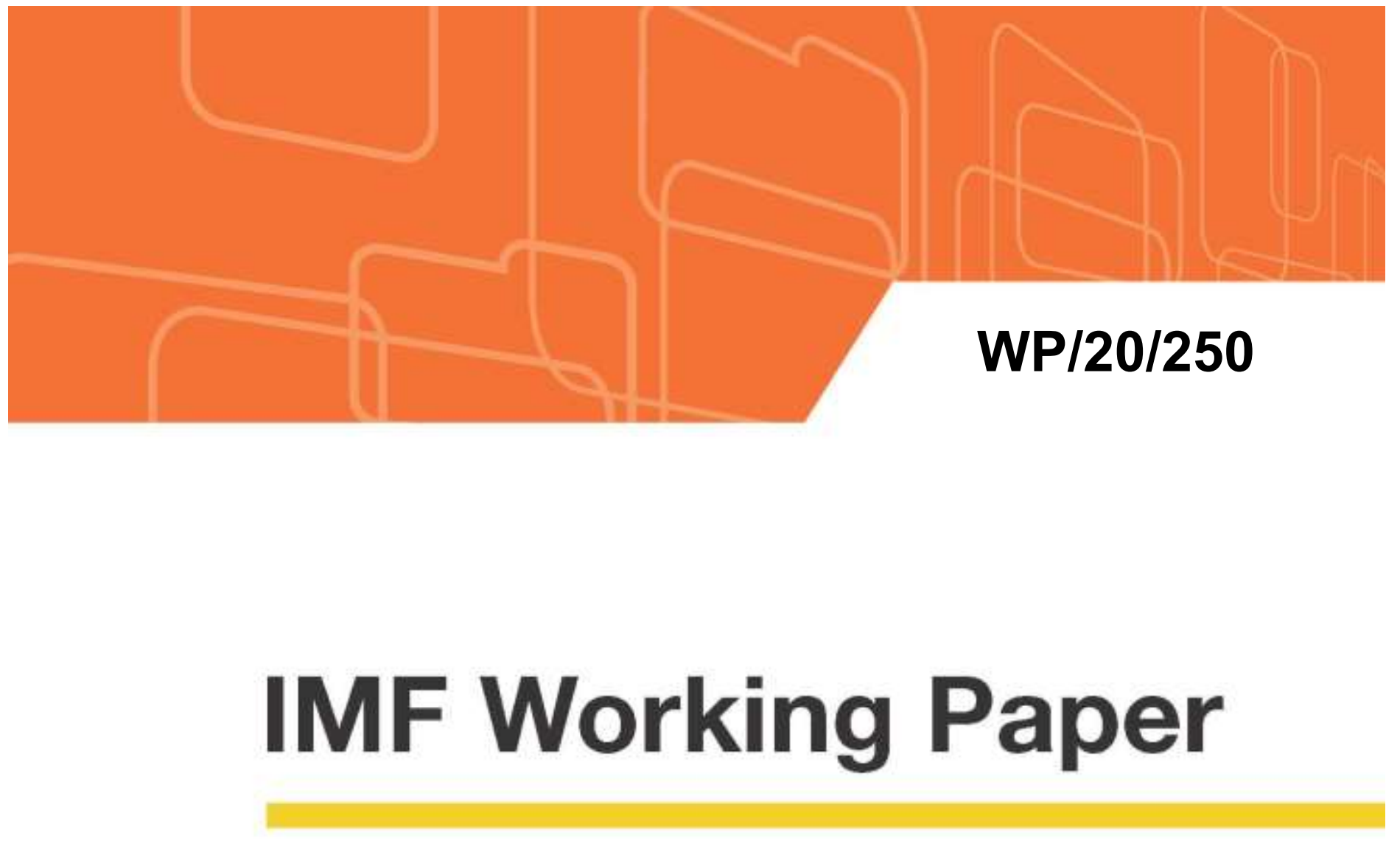

\section{Enhancing Fiscal Transparency and Reporting in India}

by Patrick Blagrave and Fabien Gonguet

IMF Working Papers describe research in progress by the author(s) and are published to elicit comments and to encourage debate. The views expressed in IMF Working Papers are those of the author(s) and do not necessarily represent the views of the IMF, its Executive Board, or IMF management. 


\title{
IMF Working Paper
}

Asia and Pacific Department \& Fiscal Affairs Department

Enhancing Fiscal Transparency and Reporting in India

Prepared by Patrick Blagrave and Fabien Gonguet ${ }^{1}$

Authorized for distribution by Ranil Salgado and Manal Fouad

November 2020

\section{IMF Working Papers describe research in progress by the author(s) and are published to elicit comments and to encourage debate. The views expressed in IMF Working Papers are those of the author(s) and do not necessarily represent the views of the IMF, its Executive Board, or IMF management.}

\begin{abstract}
Current fiscal transparency and reporting practices in India place it behind most peer G20 economies, implying that policy makers are lacking critical data to ground their fiscal and other economic planning decisions. The increasing use of off-budget financing at the central government level in recent years represents one key example of reduced transparency-we provide estimates of the public sector borrowing requirement and an extended notion of the fiscal deficit, each of which shows a more expansionary stance in recent years than 'headline' deficit figures presented in budget documents. We then investigate the current state of fiscal reporting practices in India and suggest areas for reforms - these include enhanced IT systems, stronger central-local coordination, and a gradual transition to accrual accounting.
\end{abstract}

JEL Classification Numbers: H1, H6

Keywords: Government Statistics, Budget Systems, Fiscal Reporting, India

Author’s E-Mail Address: pblagrave@imf.org, fgonguet@imf.org

\footnotetext{
${ }^{1}$ We are grateful to Marwa Alnasaa, Elif Arbatli, Antoine Arnoud, Mehdi Raissi, Ranil Salgado, Alexander Tieman, and colleagues at the Reserve Bank of India for valuable feedback, and to Nimarjit Singh for excellent research support. All fiscal data contained in this paper pre-date the COVID-19 pandemic. The opinions expressed herein are solely the responsibility of the authors and should not be interpreted as reflecting those of the IMF, its Executive Board, or IMF management
} 


\section{Table of Contents}

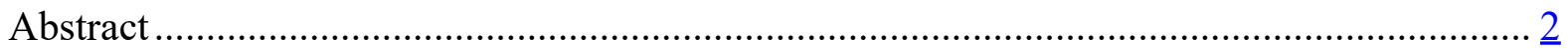

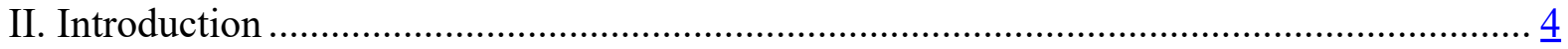

III. Going Beyond Headline Fiscal Deficits ............................................................ $\underline{5}$

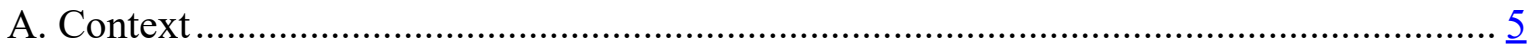

B. Public Sector Borrowing Requirement .................................................................... 7

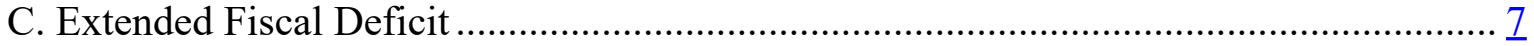

IV. Fiscal Reporting in India - Current Practices and Key Reform Priorities ....................... 9

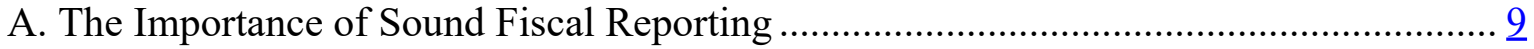

B. An Assessment of India's Fiscal Reporting Practices............................................. 10

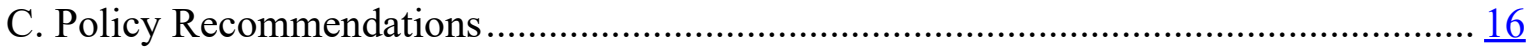

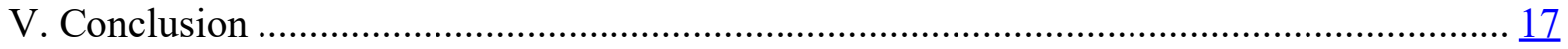

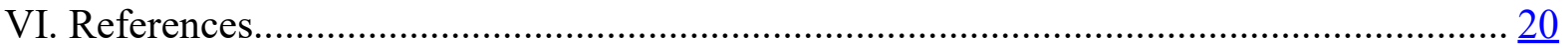




\section{INTRODUCTION}

Fiscal transparency refers to the clarity, reliability, frequency, timeliness, and relevance of the information available to the public about the government's fiscal-policy-making process, and is critical to good governance and effective economic and fiscal policy making. Yet, ensuring sound fiscal reporting, i.e. the publication and dissemination of accurate, useful summary information about the state of public finances to citizens poses several challenges. For instance, obtaining timely, frequent information from the all state and local governments and consolidating it to provide an exhaustive picture of public finances to the public is not an easy task for central governments to achieve. It is perhaps not surprising that several fiscal transparency and reporting practices in a large, federal, emerging economy such as India are behind the frontier.

However challenging, the growing role of states and public enterprises in public service delivery calls for expanding the traditional focus of fiscal reporting beyond the Union government. The reduction in the Union government's headline fiscal deficit as defined in the Fiscal Responsibility and Budget Management (FRBM) Act has been the traditional center of attention. Stopping at that, markets, investors, and citizens may consider that the Government of India (GoI) has been successful in consolidating its fiscal position in recent years. Yet, as the Union government delivers fewer public services than other public sector units (notably states and public sector undertakings (PSU) ${ }^{2}$ ) combined, ${ }^{3}$ there has been growing interest in a more complete picture of the GoI's fiscal position. This was evidenced by the strong media attention gathered by the Comptroller and Auditor General (CAG)'s estimate of India's public sector borrowing requirements (PSBR), which came at the request of the Fifteenth Finance Commission in July 2019-several think tanks and analysts also maintain estimates of India's PSBR. The COVID-19 crisis reinforces this interest, as very large fiscal measures, both above- and below-the-line as well as contingent liabilities have been adopted by the GoI in response to the economic and social effects of the pandemic.

In this paper, we document and examine the increasing use of extra budgetary resources to fund expenditures in the central government's budget in recent years - this was also examined in the IMF's 2019 Article IV Staff Report. To do this, we first construct an estimate of the public sector's borrowing requirement (PSBR) which reflects central and state government borrowing needs (that is, their fiscal deficits) but adds also the borrowing needs of central government public sector undertakings (CGPSUs). ${ }^{4}$ This metric broadly captures the government and quasi-government borrowing need, and is thus important for examining the evolution of borrowing costs facing the public sector (not an exercise conducted in this paper). India's PSBR shows that any apparent decline in central government fiscal deficits in

\footnotetext{
${ }^{2}$ The term 'public sector undertaking' is equivalent to the term 'state-owned enterprises' which is more commonly used in other countries.

${ }^{3}$ For instance, on average over the period 2015-2018, the Union government only executed 39 percent of the consolidated Center + State governments expenditure (GFS data).

${ }^{4}$ Data limitations prevent analysis of the use of extrabudgetary resources at the subnational level.
} 
recent years has been more than offset by an increase in the use of extra budgetary resources, implying an increase in the public sector's overall borrowing need.

To more directly consider the fiscal stance of the central government, we estimate an 'extended' notion of the fiscal deficit. This metric approximates the elements of CGPSU borrowings which substitute for on-budget financing of government expenditures, and is intended to approximate how the central government fiscal deficit would look if some CGPSU activities were reclassified to fall under 'government,' as opposed to 'wider public sector' activity classifications. ${ }^{5}$ According to this measure, there has been a marked increase in the central government's extended fiscal deficit in recent years, starkly at odds with the narrative suggested by the official estimate of the fiscal deficit alone, which had been gradually declining for several years (before an increase in FY2018/19).

This paper also assesses India's current fiscal reporting practices by comparing them to international best practice, as set out in the IMF's Fiscal Transparency Code (FTC), with a focus on other Group of Twenty (G20) countries. Though significant progress has been achieved recently to improve the institutional coverage of fiscal data, fiscal information is often scattered across a variety of reports and not always produced in time to be useful for decision-making. The GoI operates under a cash-basis accounting regime and tracking of assets and liabilities is very limited. And, access to information can significantly vary from one state government to the next. Enabling headway in these areas will require investment in key public financial management reforms, including information technology (IT) systems, central-local coordination mechanisms and accrual accounting standards.

The remainder of the paper is structured as follows. Section 2 presents our estimates of the general government's public sector borrowing requirement and the extended notion of the central government's fiscal deficit - these estimates come with important caveats which are also discussed. Then, section 3 discusses the importance of sound fiscal reporting practices, assesses the current state of affairs in India in this regard, and offers policy recommendations. Section 4 concludes.

\section{Going Beyond Headline Fiscal Deficits}

\section{A. Context}

Understandably, the fiscal policy debate in India mainly centers around the evolution of the central government's announced fiscal deficit - this measure is front and center in the presentation of the Union budget, widely cited by media and analysts, and its evolution is easy to track over time. However, under India's Fiscal Responsibility and Budget Management (FRBM) Act (2003), this fiscal deficit has a rather narrow definition, as it

\footnotetext{
${ }^{5}$ As per the Government Finance Statistics Manual (2001/2014), even decentralized agencies with some autonomy and own-source revenues may be considered extrabudgetary units, and thus part of the general government sector, under a broad array of circumstances. These include, but not limited to, if the agency relies heavily on government financial support, is under the direct control of the government, or is a non-market producer (output is not priced at market rate). See also Mano and Stokoe (2017) for an examination of the perimeter of government accounts in China.
} 
pertains only to flows recorded under the Consolidated Fund. By contrast, India's measured stock of debt has a broader definition, capturing the accumulation of these fiscal deficits over time, but also liabilities recorded in the public account, as well as financial liabilities of entities owned or controlled by the central government, which it repays or services. The result is a headline fiscal deficit measure which does not tell the full fiscal story-declining headline central government fiscal deficits in recent years have not been mirrored in reductions in its stock of debt.

Union budget documents contain information regarding the use of extrabudgetary resources. ${ }^{6}$ For the purpose of calculating a PSBR, this information gives us a picture of the borrowing activities of CGPSUs only - there is insufficient publicly available, timely data regarding the use of extrabudgetary resources at the subnational (state) government level, nor do we have information regarding borrowings at the local-government level (though these are believed to be small). ${ }^{7}$ At the central government level, budget documents regarding the 'resources of public enterprises,' 'extra-budgetary resources (government fully serviced bonds),' and 'sources and application of national small savings fund' form the basis for the PSBR and extended-deficit calculations considered in this section.

In the context of India's medium-term fiscal targets, the discrepancy between the definition of the fiscal deficit and debt stocks introduced by the use of off-budget financing is especially problematic. As prescribed by the FRBM review committee (2016-17), the central government fiscal deficit should be reduced to 2.5 percent of GDP, while central and state debt-to-GDP ratios should be lowered to 40 and 20 percent, respectively. ${ }^{8}$ However, the narrow definition of the deficit allows for a situation where this number can be reduced without a commensurate reduction in the debt-to-GDP ratio - this can occur if expenditures which typically would be financed through a budgetary allocation are instead financed by CGPSUs (so-called 'off-budget' financing). ${ }^{9}$ At a minimum, the inconsistency between fiscal deficits and debt dynamics creates confusion and obfuscates the true fiscal picture being communicated via the budget exercise to the general public. However, as long as the debt-toGDP target is the anchor of the government's fiscal policymaking (that is, it is given primacy over the evolution of the central government deficit when it comes to medium-term planning) then medium-term fiscal discipline is not jeopardized by the use of off-budget financing.

\footnotetext{
${ }^{6}$ The authors' understanding, from interactions with government officials, is that all CGPSUs with borrowings in a given year are listed in budget documents which form the basis for our analysis.

${ }^{7}$ As noted in RBI (2019), states also provide off-budget support to State Public Sector Enterprises (SPSEs), though there is limited information on the size of these liabilities.

${ }^{8}$ Initially, these targets were recommended to be achieved by FY2022/23. For a more complete description of the recommendations of the 2017 FRBM review committee, see Volume 1 of the FRBM Review Committee's report (Singh and others, 2017).

9 There have been other sources of discrepancy between the dynamics of the fiscal deficit and debt recently in India, including recapitalization bonds provided to public sector banks. In addition, according to the IMF's definition of the fiscal deficit, proceeds from privatization of public assets are treated below the line, and thus have no bearing on India's fiscal deficit in any given year.
} 


\section{B. Public Sector Borrowing Requirement}

As noted earlier, the PSBR metric broadly captures the government and quasi-government borrowing need and is thus important for examining the evolution of borrowing costs facing the public sector. Our estimate of the PSBR uses information from Union budget documents (relating to 'resources of public enterprises'). From these documents, we take data on all sources of CGPSU financing, except the 'internal resources' component. These borrowings are then added to the central and state government fiscal deficits to arrive at a partial estimate of the PSBR. This estimate is partial as it excludes borrowings of state and local PSUs, as well as districts and municipalities. It also bears noting that the evolution of the PSBR over time - and the contribution of new borrowings by CGPSUs - is more informative than the overall level. ${ }^{10}$

Over the past five years, new borrowings by CGPSUs have risen from

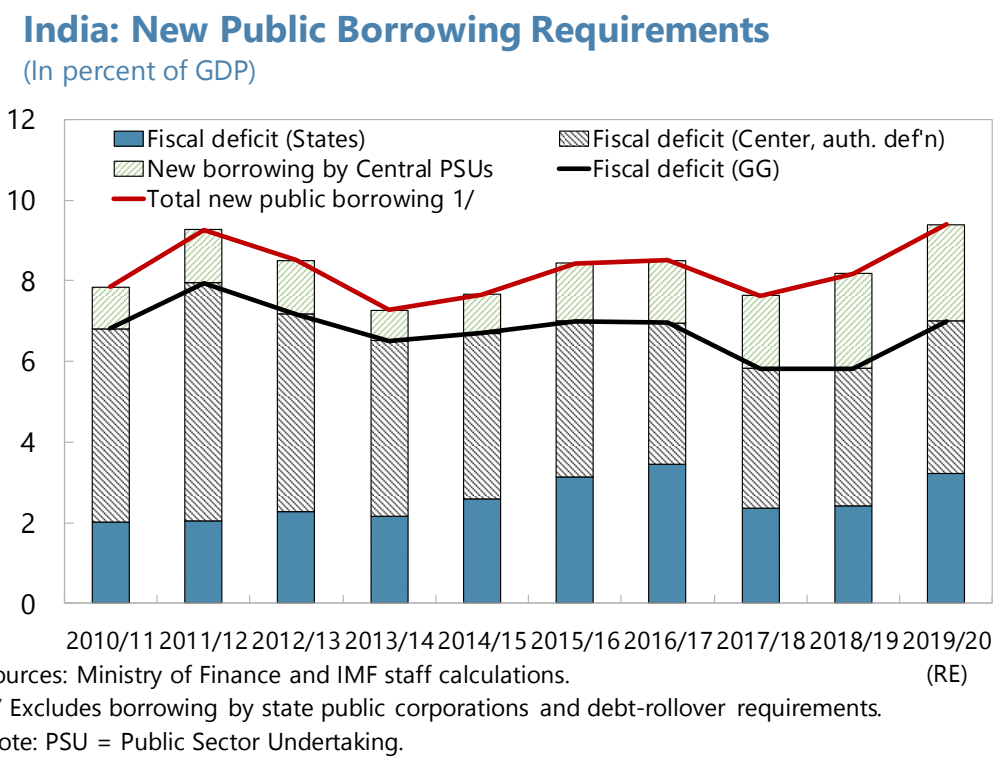

\section{India: New Public Borrowing Requirements}

12

10
0.8 percent to 2.4 percent of GDP. This implies that despite a reduction in the center's headline fiscal deficit of about 1.0 percentage point over this same time period (from 4.4 to 3.4 percent of GDP, between FY2013/14 and FY2018/19, according to the authorities' presentation of the fiscal deficit ${ }^{11}$ ), the central government's overall PSBR (the sum of its headline deficit and the borrowings of its PSUs) has increased (from 5.2 to 5.8 percent). Estimates for FY2019/20 provided in the Union budget imply a similar level of CGPSU borrowings in that fiscal year, though this will remain highly uncertain until after the end of the fiscal year, especially in the context of the COVID-19 pandemic.

\section{Extended Fiscal Deficit}

Constructing an extended notion of the central government's fiscal deficit entails making judgments regarding which elements of the aforementioned borrowings by CGPSUs (those included in the PSBR) should be considered 'quasi government expenditures,' and thus

\footnotetext{
${ }^{10}$ Some level of borrowings by CGPSUs entities would be considered 'normal' (that is, a baseline against which deviations could be weighed) and thus it is hard to assess how large we should expect these borrowings to be.

11 The IMF definition of the fiscal deficit follows GFSM 2014 standards and treats non-debt capital receipts (mainly in the form of proceeds from disinvestment of public-sector assets) below the line. In addition, the IMF treats revenues from departmental commercial undertakings above the line (whereas the Government of India excludes these revenues from its fiscal deficit calculation).
} 
within the parameter of the government's activities. To arrive at our extended notion of the fiscal deficit, we add two elements to the central government's headline fiscal deficit:

- $\quad$ Financing for CGPSUs which comes from the National Small Savings Fund (NSSF)

- $\quad$ New issuances of government fully serviced bonds

Both items have a bearing on the government's debt stock, either directly (in the case of NSSF loans) or at some point in the future (in the case of fully serviced bonds, whose ultimate repayment does not count against the debt until it comes due). The most obvious example of how NSSF loans are being used to finance government spending, via CGPSUs, relates to the case of the Food Corporation of India (FCI) - see Table 1. Since FY2016/17, the central government has been deferring on-budget subsidy payments to the FCI, with the effect of reducing on-budget expenditures and lowering its headline fiscal deficit. The amount of new deferrals has been between 0.3 and 0.4 percent of GDP each year since they began. To ensure that the FCI's operations continue, it has received loans from the NSSF to cover these annual shortfalls vis-à-vis its budgetary allocation. ${ }^{12}$ The central government's extended fiscal deficit has risen from 3.9 in FY2016/17 to 4.6 percent of GDP in FY2018/19 (Table 2). ${ }^{13}$

Table 1. India: Off-budget financing through NSSF loans (percent of GDP)

\begin{tabular}{|l|c|c|c|c|}
\hline & FY2015/16 FY2016/17 FY2017/18 FY2018/19 \\
\hline Total NSSF net new loans to public agencies & - & 0.41 & 0.48 & 0.54 \\
o/w & - & & & \\
Food Corporation of India & - & -41 & 0.27 & 0.34 \\
NHAI & - & - & 0.11 & 0.10 \\
Air India & - & - & 0.02 & 0.00 \\
BMTPC & - & - & 0.05 & 0.00 \\
IRFC & - & - & - & 0.04 \\
PFC & - & - & - & 0.02 \\
REC Ltd & -
\end{tabular}

Sources: 'Sources and Applications of National Small Savings Fund' Indian Union Budget document (Annex 8 for FYs 2018/19, 19/20, and 20/21, Annex 6b for FY 17/18) and Authors' calculations Notes: Figures report additional loans, net of repayments during the FY

\footnotetext{
12 See Comptroller and Auditor General (2018) for further discussion.

${ }^{13}$ Recent estimates compiled by other analysts are generally comparable to this estimate. The most publicized public estimate is that of Garg (2020), which includes recapitalization bonds for public sector banks (which are excluded from our analysis). His estimate also includes a smaller set of CGPSU expenditures financed by loans from the NSSF - namely, only those going to the Food Corporation of India and Building Materials and Technology Corporation - than what is included in this paper (all NSSF loans to CGPSUs), but treats fully serviced government bonds in the same was as we do.
} 
Table 2. India: Extended fiscal deficit (percent of GDP) Extended fiscal deficit (percent of GDP)

\begin{tabular}{|l|c|c|c|}
\hline & FY2016/17 & FY2017/18 & FY2018/19 \\
\hline Central government fiscal deficit (authorities' definition) & 3.5 & 3.4 & 3.8 \\
Off-budget financing & 0.4 & 0.5 & 0.5 \\
Government 'fully serviced' bonds & 0.1 & 0.1 & 0.3 \\
Extended fiscal deficit & $\mathbf{3 . 9}$ & $\mathbf{4 . 0}$ & $\mathbf{4 . 6}$ \\
\hline
\end{tabular}

Sources: Union Budget documents (Annex 8; Statement 27) and Authors' calculations

\section{Fiscal Reporting in India - CurRent Practices ANd Key Reform Priorities}

This section is divided into three parts. We begin with a brief motivation for the importance of sound fiscal reporting, before proceeding to assess the current state of India's fiscalreporting practices, and then concluding with policy recommendations.

\section{A. The Importance of Sound Fiscal Reporting}

The uncertainty regarding India's actual fiscal stance is a limitation to sound economic policy making. Contrary to what headline central deficit numbers have indicated, analysis in the preceding section shows that fiscal policy was more expansionary. This knowledge is important to decide on what should be the right fiscal/monetary policy mix, and what fiscal space is available, especially in the current context of the COVID-19 pandemic. Further, the fact that the PSBR exceeds net household financial savings suggests that the private sector could be crowded out from investing - an obstacle to the realization of India's potential growth that goes unnoticed when only considering the Union government's fiscal stance.

In particular, though state governments are granted fiscal and financial autonomy by the Constitution, India would benefit from regular monitoring of state finances by the center. To preserve fiscal sustainability while states are responsible for an increasing share of spending, the Union government needs to (1) foster good governance and fiscal discipline at the state level; and (2) be aware of fiscal developments across states in order to proactively manage or mitigate pending issues that could affect the overall fiscal position of the country. In particular, the Union government's decision makers should be able to identify the key fiscal risks that could stem from state governments or state-level PSUs and ultimately entail significant costs for the center (from unpaid taxes or lower dividends to large bailouts). Risks can originate from explicit obligations of the central government from the states (in the form of legal or contractual arrangements) or implicit obligations based on expectations that the center will support struggling states or PSUs. ${ }^{14}$ Cross-country analysis of fiscal risk materializations over the past 25 years shows that the realization of contingent liabilities, be they explicit or implicit, leads to significant average fiscal costs: for example, 9.7 percent of

\footnotetext{
${ }^{14}$ The Constitution suggests that the Union may have to step up in case of severe fiscal distress at the state level. Though never used yet, Article 360 of the Constitution states that if the President considers that there is an economic situation in which the financial stability or credit of India or any part of the territory is threatened, he or she can declare a financial emergency. Under such a regime, all financial state decisions would have to be confirmed by the President, who could also decide on the reduction of salaries and allowances.
} 
GDP for contingent liabilities in the financial sector, 3.7 percent of GDP for the bailout of subnational governments, or 3.0 percent for the bailout of state-owned enterprises (Bova et al., 2016). Some bailout episodes have led to costs as high as 12 to 15 percent of GDP. The recent assumption by the state governments of liabilities from the state power distribution companies (DISCOM) highlights the need for deeper oversight of state-level PSUs both by the Union and state governments.

Stronger fiscal transparency could reinforce the credibility and fiscal performance of the GoI. Empirical evidence (IMF, 2012) points to a positive relationship between the degree of fiscal transparency and low debt levels, with a stronger correlation in lower and middle-income countries; further, fiscally transparent countries seem to be rewarded with more favorable market borrowing conditions, with a negative relationship between the level of fiscal transparency and credit-default-swap spreads on sovereign debt. Overall, fiscal transparency boosts the ability of markets, investors, and citizens to make informed and efficient financial and economic decisions. It also facilitates international fiscal comparisons and helps these agents to anticipate and mitigate cross-country fiscal spillovers. And fiscal transparency contributes to ensuring that governments are taking steps to achieve key fiscal policy objectives and goals, through for instance the release of targets and indicators and ex post reports on execution.

The exceptional scale of the fiscal response to the COVID-19 crisis makes sound fiscal reporting and transparency even more critical. Governments need to be able to accurately and reliably monitor the ever-changing fiscal position in a context of heightened uncertainty. They also need to preserve transparency and accountability on the massive fiscal measures adopted to tackle the pandemic, so as to enable economic actors to understand and access them, to ensure confidence that public monies are effectively and efficiently used, and to provide a sense of the medium- to long-term risks associated with the response. In particular, given the fiscal risks associated with off-budget measures, it is important to adopt and communicate upfront clear and transparent criteria to identify beneficiaries (Wendling et al., 2020). More frequent reporting may also be warranted when the crisis is most acute, so as to enable policymakers to track the effects of their policies and to allow for rapid changes if needed.

\section{B. An Assessment of India's Fiscal Reporting Practices}

This section assesses India's fiscal reporting practices across four dimensions. Fiscal reporting is the preparation and publication of summary information about the past and present state of a country's public finances, in the shape of budget execution reports, fiscal statistics, or government financial statements (IMF, 2012). It is a key prerequisite for sound financial management, that should provide the most accurate understanding of the government's fiscal position to markets, investors, citizens, and to the government itself. This paper will focus on four key dimensions of fiscal reporting practices:

(1) the institutional coverage of fiscal reports, which should be as wide as possible and avoid excluding significant parts of government activity from public scrutiny;

(2) the timeliness and frequency of fiscal reports, including in-year, so that they can usefully support fiscal planning and budgeting; 
(3) the comprehensiveness of information about fiscal flows and stocks, which helps ensure a full understanding of the fiscal position and net worth of the government and provide a complete account of how public resources are used and committed over the medium-term;

(4) the ease of access to fiscal information for all.

To get a complete picture of India's fiscal reporting practices, a Fiscal Transparency Evaluation (FTE) would be useful. Carried out at the request of governments, FTEs assess country practices against standards set in the IMF's Fiscal Transparency Code (FTC, 2014, revised in 2019). Beyond the assessment of fiscal reporting practices, FTEs evaluate the contents of budget documents and the quality of fiscal forecasts, as well as fiscal risk management practices, and provide countries with an analysis of the sources of fiscal vulnerability across the public sector. In particular, FTE reports often include a public sector balance sheet and a measure of contingent liabilities and fiscal risks. ${ }^{15}$

\section{Institutional coverage}

Substantial fiscal information is available on the major public sector units, but loopholes exist at lower tiers of government. Budget execution data for the Union government is compiled on a monthly basis by the Controller General of Accounts (CGA). Monthly execution data for state governments is also produced by states' accountants general but not systematically made available to the public. Public debt statistics are compiled by the Reserve Bank of India (RBI) and quarterly reports are produced by the Ministry of Finance (MoF). The MoF's annual Economic Survey and RBI's annual report on state finances provide data and in-depth analyses of recent fiscal trends for both the Union and states. A Public Enterprises Survey is produced every year by the Ministry of Heavy Industries and Public Enterprises, providing a comprehensive account of the performance of central public sector enterprises. Yet, several subsectors are not reported on in a consolidated fashion. There is no available fiscal information on districts or on municipalities. Some states produce reports on state-level PSUs, but there is no repository that would compile all information together on these state enterprises. The recent assumption by the state governments of liabilities from the state electricity distribution companies highlights the need for enhanced oversight of state-level PSUs both by the Union and state governments.

Financial information on the government fiscal position are not comprehensive and can be misleading. Operations counted in the calculation of the Union's fiscal deficit (according to the definition set in the FRBM Act) are limited to the Consolidated Fund of India, the most significant of the three main accounts of the Union government's budget. The other two accounts - the Contingency fund and the Public account of India (operations for which the central government acts as a trustee) - are not counted as part of the deficit, while they are covered by the FRBM Act's definition of public debt. The Public account includes the

\footnotetext{
${ }^{15}$ For more information on the IMF's work on fiscal transparency and to browse through existing FTE reports, please visit www.imf.org/fiscaltransparency.
} 
National Small Savings Fund (NSSF), which has increasingly been providing loans to central PSUs to offset the deferral of central government subsidies. Though notable efforts have been made by the government to release information on these extrabudgetary resources and off-budget operations in the budget documents (Statements 25 and 27, Annex 7 of the July 2019 Union Budget), information remains scattered across a variety of reports.

India is a clear outlier among peer countries in terms of production of consolidated general government fiscal data. A combined deficit for the Union and state governments is presented on an annual basis in the Economic Survey, and consolidated Union/States data is published as part of the MoF's Indian Public Finance Statistics. ${ }^{16}$ Since December 2018, the RBI also publishes a mid-year review of government finances, combining Union government and state-level information (for 24 out of 29 states); and in December 2019, the RBI published for the first time a quarterly consolidated account of the Union and 24 states. Yet, there is no information on lower tiers of government, which would be needed to provide a full vision of general government. India is only one of three G20 countries (with Saudi Arabia and Argentina) which does not produce or report full general government data in line with GFS standards. India's commitment under the G20 Data Gaps Initiative to compile and disseminate quarterly GFS covering the consolidated general government by 2021 is a step in the right direction; but as of 2019, India is the only country which has not recorded any progress in meeting this requirement. Useful lessons can be drawn from Brazil, a large federal emerging market country which has managed to produce consolidated general government data within a few years by setting up a dedicated IT system and smart incentives for states to share their fiscal data on a timely basis (see Box).

\footnotetext{
${ }^{16}$ The RBI also publishes consolidated Union/states deficit and debt numbers in its September/October bulletin, albeit with lower granularity.
} 
Table 3. India: Progress in Meeting GFS Recommendation as Part of Phase II of the G20 Data Gaps Initiative

\begin{tabular}{|c|c|c|}
\hline \multicolumn{3}{|c|}{$\begin{array}{c}\text { Recommendation II.15. Government Finance Statistics - Disseminate quarterly General Government } \\
\text { Data in line with GFSM } 2014 \text { by } 2021\end{array}$} \\
\hline Country & $\begin{array}{l}\text { Target fully / } \\
\text { partially / not } \\
\text { met }\end{array}$ & Comments \\
\hline Argentina & & CG reported annually in line with GFSM14. \\
\hline \multicolumn{3}{|l|}{ Australia } \\
\hline \multicolumn{3}{|l|}{ Brazil } \\
\hline \multicolumn{3}{|l|}{ Canada } \\
\hline China & & GG reported annually in line with GFSM14. \\
\hline \multicolumn{3}{|l|}{ France } \\
\hline \multicolumn{3}{|l|}{ Germany } \\
\hline \multicolumn{3}{|l|}{ India } \\
\hline \multicolumn{3}{|l|}{ Indonesia } \\
\hline \multicolumn{3}{|l|}{ Italy } \\
\hline Japan & & GG reported annually in line with GFSM14. \\
\hline Korea & & GG reported annually in line with GFSM14. \\
\hline \multicolumn{3}{|l|}{ Mexico } \\
\hline \multicolumn{3}{|l|}{ Russia } \\
\hline Saudi Arabia & & Parts of CG reported annually in line with GFSM14. \\
\hline \multicolumn{3}{|l|}{ South Africa } \\
\hline \multicolumn{3}{|l|}{ Turkey } \\
\hline \multicolumn{3}{|l|}{ United Kingdom } \\
\hline \multicolumn{3}{|l|}{ United States } \\
\hline European Union & & \\
\hline
\end{tabular}

Source: IMF/FSB, Fourth Progress Report of Second Phase of G20 Data Gaps Initiative, 2019.

\section{Timeliness and frequency}

Except for the Union government, frequency and timeliness of in-year fiscal information are limited in India. Union budget execution data are released monthly with a month lag, in line with best international practices. The RBI's mid-year review is published with a two-month lag. Other types of in-year information however are not as frequent or timely. For instance, monthly state-level information is produced with several months' lag at the level of each state, and not systematically published. Public debt reports are produced on a quarterly basis by the MoF, with a quarter lag (a level of practice rated as "Basic" according to the IMF's FTC). Producing quarterly general government information within a month of the end of the quarter would enable the Union government to take prompt corrective action, if overall fiscal performance veers off course.

The timeliness of audited annual financial statements could also be improved. The Union government's audited annual financial statement is released by the CAG within a year, at the earliest. The combined Union and state financial accounts are produced by the MoF two years after the end of the fiscal year - these are not an audited statement, but rather a compilation of all audited financial statements from Union and state governments. Financial information produced with more than a one-year lag is of little use for fiscal policy making. 
Such lags also make it hard to correct irregularities that may have been noted by the auditor. In the case of India, a release within seven to nine months should be targeted, so that audited statements can have an impact on budget preparation.

\section{Comprehensiveness}

The GoI operates under a cash-basis accounting regime. A pure cash-accounting system presents limitations from the standpoint of fiscal transparency. Under a cash-accounting regime, financial transactions are recorded when there is an exchange of cash. There is no tracking of receivables and payables, nor of assets and liabilities. This opens the possibility to present misleading cash balances by artificially deferring cash disbursements to the following year. The CAG has identified several cases of such anomalies for the Union and some states in its audit reports. Such deferrals can also have implications for economic activity, insofar as the delay of receivable funds curtails firms' ability to spend or forces them to borrow to bridge the gap until disbursements are paid out.

The cash basis is complemented by emerging elements of accrual accounting, both at the level of the Union and state governments. Statements of liabilities of the central and state governments, covering mostly debt obligations and loans, are reported on a regular basis by the MoF as part of budget documentation for the former and by the RBI in the context of the annual report on state finances for the latter.

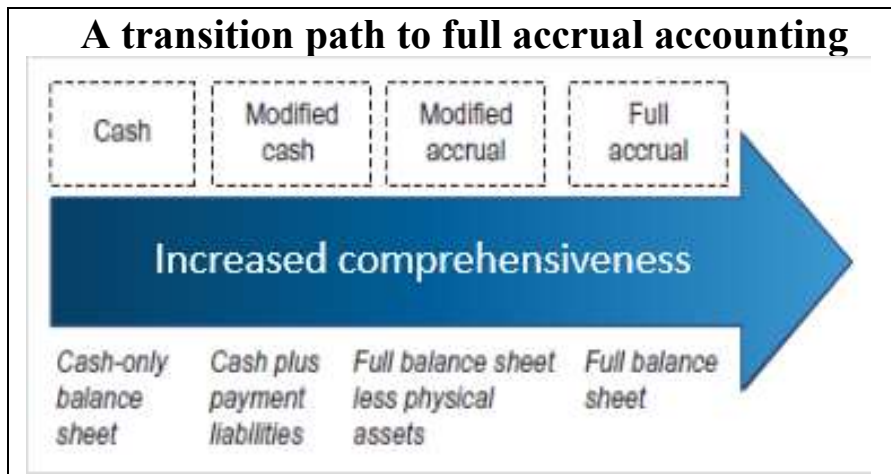

Source: Cavanaugh et al. (2016) Government accounts also record financial assets, though their valuation is not regularly updated. Some state governments are more advanced than others in terms of records of assets and liabilities. The main shortcomings lie in: (i) the absence of systematic nonfinancial asset registers, both at the center and state levels, ${ }^{17}$ (ii) the lack of reporting on public pension liabilities; (iii) the absence of recording of contingent liabilities other than explicit government guarantees; and (iv) the lack of commitment control mechanisms at the Union level and in most states. Overall, the wide variation in the level and quality of reported accrual information prevents any attempt to produce a consolidated general government balance sheet.

Initiating the transition to accrual accounting would bring India in line with most peer countries. Such a transition would gradually enable the GoI to achieve more active and efficient asset management, to have a complete vision of the use of public resources, and, ultimately, to make use of the analytical power of public sector balance sheets. It is possible for large, federal, emerging market economies like India to move ahead with these reforms, but they usually take at least seven years, as they require sound IT systems and aligned charts

\footnotetext{
17 The CGA is currently working on the creation of an e-asset register for nonfinancial assets, which would automatically record new fixed assets when they are procured.
} 
of accounts. Many countries, mostly OECD, have moved to accrual accounting; and most large emerging market economies, including Brazil and China, are moving towards it, including at the provincial/state level. According to the International Federation of Accountants, countries working under a pure cash accounting basis represent only 30 percent of all 150 countries it tracks, India being the last large emerging market economy which has not kickstarted a transition to accrual accounting. Such a transition has been recommended as an important reform by the $12^{\text {th }}, 13^{\text {th }}$, and $14^{\text {th }}$ Finance Commissions, but there is, as yet, no clear reform strategy to materialize it. In 2002, the GoI created the Government Accounting Standards Advisory Board under the guidance of CAG. Yet, only cash-basis standards have been issued and notified by the Board as of today.

\section{Access to fiscal information}

Though the exhaustiveness of fiscal information available to the public has progressed, it remains difficult for non-specialists to fully understand how public resources are used. The release of more data does not necessarily imply more transparency. Instead of leaving the task of parsing the key takeaways regarding India's fiscal position and strategy from myriad reports and budget documents to the media and analysts in financial institutions and think tanks, the Union and state governments should consider providing more user-friendly information and narratives, alongside or ahead of their budgets and financial statements. The key reason why the Union government obtained a score of 49/100 in the Open Budget Survey 2019 (against a global average of 45) is the absence of a forward-looking fiscal strategy document which would be made available several months before the budget and provide a comprehensive picture of public finances in the medium term.

A major challenge lies in the fact that an Indian citizen, depending on her/his state of origin, does not have equal access to fiscal information. According to a 2020 survey by Transparency International India, based on a methodology to measure transparency in budget processes at the Union and state government levels, only the Union government can be considered as having a transparent budget. Assam, Andhra Pradesh, Odisha, and Jharkhand are the only four states displaying medium levels of budget transparency. All other states either display low levels of transparency, or, for nine of them, are considered to have opaque budget practices. The contents of the budget documents should ideally be standardized across the Union and state governments, in order to ensure that each citizen has equal access to fiscal information, regardless of the state of origin. 


\section{Score of Indian States in Budget Transparency (scale: 0-100)}

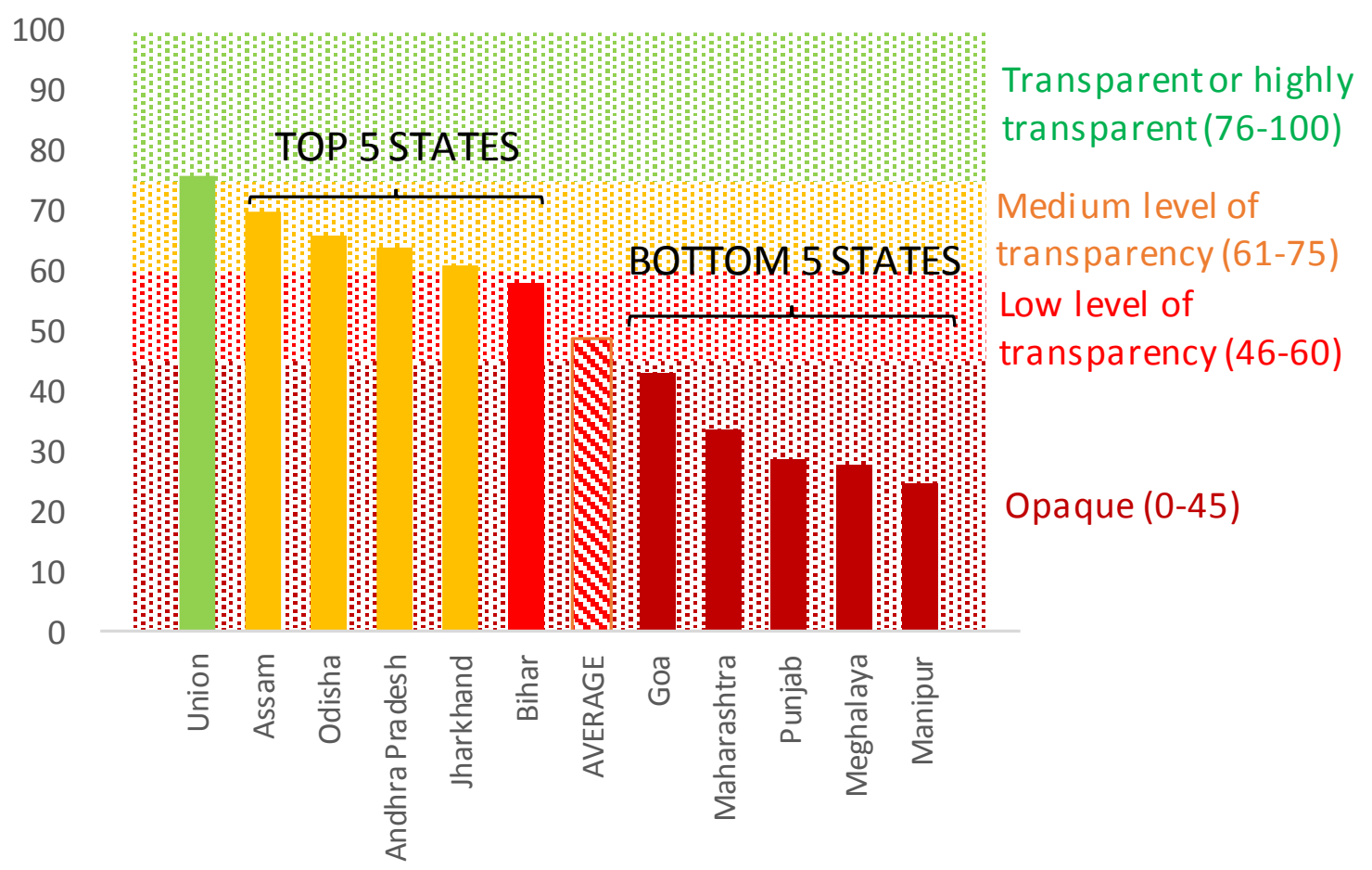

Source: Transparency International India (2020). The score covers four dimensions: public disclosure and accessibility of important budget documents (40 points), participatory and inclusive budgetary process (25 points), post-budget fiscal management and transparency ( 25 points), and special efforts to make budget more transparent and citizen-friendly (10 points).

\section{Policy Recommendations}

The GoI should consider investing in three key reform pillars for enhanced fiscal reporting. The timeliness of reporting could be improved through enhanced IT systems that are able to deliver and consolidate comprehensive information on a high-frequency basis. The Union and state governments have been using multiple Financial Management Information Systems (FMIS) solutions. While it is possible to operate with such a diversity of systems (as long as there are well-designed interfaces and a common "language"18 to facilitate data exchanges), it is critical, for consolidation purposes, to set clear standards on which information should be collected and compiled, and to ensure that the relevant information is shared on a timely basis by all stakeholders. Setting up a dedicated platform for all government units to share their fiscal information (similar to Brazil, see Box) could be a practical solution for the consolidation exercise.

The Union government should reinforce its role as the guardian of fiscal sustainability and foster stronger center-state coordination. It is critical for the Union government to have a

\footnotetext{
${ }^{18}$ According to the Constitution, the CGA is in charge of prescribing the form of accounts for the Union government and states (Article 150). Currently, the Union and state governments are sharing the first nine digits of the 15-digit Chart of Accounts, but a few central and state ministries still need to be integrated into the Chart. The Chart will have to be amended to respond to the upcoming requirements of GFSM 2014.
} 
regular look at the fiscal position of states (as well as other public sector entities, including PSUs, at both national and state levels), with a clear understanding of fiscal risks associated with them. For consolidation to be achieved on a quarterly basis, the Union should set common, consistent reporting and transparency standards across all levels of government: a shared calendar, a common format for information sharing, common standards for fiscal reports; and possibly financial incentives for states to report on a timely basis, similar to Brazil (see Box). The Union could also support lower tiers of government thorough guidelines, templates, and training.

The GoI should increase the comprehensiveness of fiscal reports through the gradual move to accrual accounting across the Union and state governments. Such a move takes on average seven to ten years, hence requiring a clear medium-term strategy, anchored by explicit objectives and milestones. This strategy could include reform streams already in motion (such as the e-asset register initiative). A public sector balance sheet could gradually be put together and used to monitor risks and make more informed decisions about asset management.

In the short run, a few immediate steps could bring significant improvements to current fiscal reporting:

- $\quad$ The Union government should clearly designate the agency/unit in charge of spearheading the consolidation exercise.

- The Union should set common standards for information sharing by States, so that consolidation can be achieved on a timely basis; this includes preparing a template for regular fiscal reporting and a calendar for data collection and publication.

- $\quad$ The Union government should move towards the calculation of a full central government deficit in line with GFSM 2014, along with a commitment to refrain from deferring cash payments, including unduly delaying tax refunds, and recourse to offbudget operations.

- A list of major state-level PSUs should be put together to assess fiscal risks related to them. Existing asset registries at the Union and state levels should be compiled and consolidated to draw up a first rough picture of general government assets.

\section{Conclusion}

Enhancing fiscal reporting in India is challenging, due to the large size of the country and to the many tiers of government which contribute to public service delivery. But it is critical, because the majority of government activities take place outside of the Union government's scope. Yet, the provision of a full picture of India's public finances by the Union government can only be successful if capacity to provide that information is developed across all levels of the public sector. Some states are more advanced than others in that respect, with ad hoc IT systems, and, in some cases, collection of accrual data. Yet, capacity development remains 
vital across the board to ensure that a consolidated picture can be produced centrally on a timely, frequent basis.

The Union government should also continue leading by example by setting common reporting and budgeting standards for all tiers of government, including itself. This includes providing an extended picture of its fiscal activities by disclosing extra budgetary activities in a clearer manner and fully integrating them in the presentation of the Union-level fiscal stance - possibly making use of the methodologies presented in this paper.

Finally, through its fiscal reports, the GoI should allow investors, markets, and the general public to better understand the government's actual fiscal stance. The release of more data does not necessarily imply more transparency. Information is scattered across many documents and websites, making it difficult for economic agents to obtain a full account of the use of public resources on which to base their decisions and choices. Further, there are very few published forward-looking analyses of the fiscal risks borne by the Union and state governments, respectively, in many cases due to the absence of proper monitoring processes. Instead of leaving that task to the media and analysts in financial institutions and think tanks, the Union and state governments should consider providing more user-friendly and forwardlooking information and narratives, alongside or ahead of their budgets, for example as part of a fiscal strategy statement. 
Box. Lessons from the Brazilian experience on the consolidation of fiscal accounts

Brazil's fiscal reporting framework is a relevant example for India to consider. Like India, Brazil is a large emerging market economy, the ninth largest in the world (2018). Both countries also share a federal setting. Brazil's general government sector comprises the Union government, 27 states, and more than 5,500 municipalities. Both countries also display a large state-owned enterprise sector. There are more than 1,000 public sector enterprises in Brazil (including at state and municipal levels). Hence, the fiscal reporting reforms successfully undertaken by Brazil over the past decade are a useful point of reference for India.

Brazil manages to report a comprehensive consolidated general government deficit on a regular, timely basis. Brazil's Fiscal Responsibility Law (FRL, 2000) contained a strong requirement for all levels of government to regularly report on the state of their finances. At the time, most states and municipalities were already recording fiscal information in their own financial management information systems (FMIS), but it was difficult to obtain a consolidated picture across the general government. In 2010-2011, the Union government decided to develop the Brazilian Public Sector Fiscal and Financial Information System (SICONFI), an integrated IT system aimed to connect all states and municipalities, acting as a platform to submit fiscal data on a regular basis, with the possibility of being automatically linked with local FMIS systems. SICONFI was developed and deployed to all state and local governments over a period of four years. Since April 2016, the National Treasury publishes quarterly general government data on a modified cash basis, in line with GFSM 2014 format - placing Brazil in compliance with the G20 Data gaps Initiative requirement. In parallel, Brazil has also been gradually transitioning to accrual accounting across all government bodies, following to a ten-year timeline for the convergence to international standards.

Key reasons for Brazil's successful consolidation of fiscal accounts include: (1) $a$ solid starting point. Before Brazil initiated its fiscal reporting reform journey, a set of important prerequisites were already met with, including existing fiscal reporting IT systems in most state and local governments and a Chart of accounts shared by all levels of government; (2) a strong reform strategy. The development of SICONFI was spearheaded by the National Treasury, which set out a timeline and clear roles and responsibilities ahead of the deployment of the system; (3) effective incentive mechanisms. In case a state or municipality does not submit its fiscal data on time, it becomes unable to borrow and ineligible to receive certain types of central transfers. 


\section{REFERENCES}

Allen, R. (ed.), R. Hemming, and B. Potter, 2013. The International Handbook of Public Financial Management, Palgrave Macmillan, New York, NY.

Bova, E., M. Ruiz-Arranz, F. G. Toscani, and H. E. Ture, 2016, "The Fiscal Costs of Contingent Liabilities: A New Dataset," IMF Working Paper No. 16/14, Washington DC.

Cavanaugh, J., S. Flynn, and D. Moretti, 2016, "Implementing Accrual Accounting in the Public Sector," IMF Technical Notes and Manuals 16/06, Washington DC.

Comptroller and Auditor General of India, 2018, Report on Compliance of the Fiscal Responsibility and Budget Management Act, 2003, for year 2016-17 Union Government (Civil), Department of Economic Affairs (Ministry of Finance) Report no. 20, Delhi, India.

Cooper, J., and S. Pattanayak, 2011. "Chart of Accounts: A Critical Element of the Public Financial Management Framework," IMF Technical Notes and Manuals 11/03, Washington DC.

Singh, N.K., S. Bose, U. Patel, A. Subramanian, and R. Roy, 2017. "FRBM Review Committee Report: Volume 1, Responsible Growth - A Debt and Fiscal Framework for $21^{\text {st }}$ Century India"

https://dea.gov.in/sites/default/files/Volume\%201\%20FRBM\%20Review\%20Committee\%20 Report.pdf, accessed September 22, 2020.

Garg, S, 2020, "Comprehensive Note on Fiscal Deficit and Debt in India" Blog post https://subhashchandragarg.blogspot.com/2020/01/comprehensive-note-on-fiscal-deficit.html

International Federation of Accountants, 2018. International Public Sector Financial Accountability Index - 2018 Status Report, New York, NY.

International Monetary Fund, 2012, "Fiscal Transparency, Accountability, and Risk," IMF Policy Paper, August 2012, Washington DC.

International Monetary Fund, 2018a, Fiscal Transparency Handbook, Washington DC. International Monetary Fund, 2018b, Managing Public Wealth, Fiscal Monitor, October 2018, Washington DC.

International Monetary Fund, 2019a, Fiscal Transparency Code, Washington DC.

International Monetary Fund and Financial Stability Board, 2019b, G20 Data Gaps Initiative - The Fourth Progress Report: Countdown to 2021, Washington DC.

Mano, R., and P. Stokoe, 2017, "Reassessing the Perimeter of Government Accounts in China”, IMF Working Paper 17/272, Washington DC.

Reserve Bank of India, 2019, State Finances: A Study of Budgets of 2019-20, September, Mumbai, India.

Transparency International India, 2020, Transparency in Budgetary Process - Third Edition, New Delhi India.

Una, G., R. Allen, and N. Botton, 2019. "How To Design a Financial Management Information System - A Modular Approach," IMF How-To Notes 19/02, Fiscal Affairs Department, Washington DC. 
Wendling, C., V. Alonso, S. Saxena, V. Tang and C. Verdugo, 2020. "Keeping the Receipts:

Transparency, Accountability, and Legitimacy in Emergency Responses", IMF Special Series on Fiscal Policies to Respond to COVID-19, Fiscal Affairs Department, Washington DC. 